\title{
КРАНИОЛОГИЧЕСКИЙ АСПЕКТ ГЕНЕЗИСА НАСЕЛЕНИЯ ТРОПИЧЕСКОЙ ТРАНССАХАРСКОЙ АФРИКИ*
}

\begin{abstract}
Настоящая работа продолжает краниологическое исследование по типологии ростовых прочессов мозгового черепа. Изучалось современное население тропической транссахарской Африки. Анализировались краниосерии территории Габона и бассейна реки Конго - западная часть изучаемого региона, а также серии восточноафриканских земледельцев и капоидов (бушменов и готтентотов) - восточная часть изучаемого региона. Отдельно рассматривались мужские и женские краниосерии. Некоторые краниосерии удалось разбить на фракции, различающиеся по типу ростовых прочессов черепа. Сравнительный анализ показал, что краниосерии (и их фракиии) западной части изучаемого региона, как иелое, серьёзно отличаются от таковых восточной части по форме черепной коробки. Это отчётливо видно на мужских сериях, но менее очевидно при сравнении женских серий. По общему размеру черепной коробки в западной части изучаемого региона наблюдается значительно большая дисперсия, чем на его востоке. Это является следствием того, что в экваториальных дождевых лесах в негрских популяциях налицо примесь пигмеев, для которых характерна малая величина черепной коробки. Такого отличия между земледельцами Восточной Африки и краниологически похожими на них капоидами (бушмены и готтентоты) не наблюдается. Отсюда следует два основных вывода. Во-первых, население западной (гумидной) части экваториальной Африки сложилось в результате смешения более крупноголовых носителей негрских земледельческих культур с пигмеями, имевших заметно меньшую величину черепной коробки. Среди собственно негрских краниосерий здесь выделяются ростовые фракции не отличающиеся от пигмеев. Во-вторых, земледельческое население восточной (более аридной)
\end{abstract}

Пестряков Александр Петрович - к.и.н., старший научный сотрудник, Институт этнологии и антропологии РАН (Москва, Ленинский пр. 32-а). Эл. почта: labrecon@yandex.ru. Pestriakov, Aleksandr P. - PhD in Hist., Institute of Ethnology and Anthropology, RAS (Moscow, Russia). E-mail: labrecon@yandex.ru

Григорьева Ольга Михайловна - к.и.н., старший научный сотрудник, Институт этнологии и антропологии РАН (Москва, Ленинский пр. 32-а) Эл. почта: labrecon@yandex.ru. Grigorieva, Olga M. - PhD in Hist., Institute of Ethnology and Anthropology, RAS (Moscow, Russia). E-mail: labrecon@yandex.ru

Пеленицына Юлия Вадимовна - студентка 4 курса, Российский Государственный Гуманитарный Университет. (Москва, Миусская площадь, 6). Эл. почта: j.pelenitsyna@gmail. Pelenitsyna, Yulia V. - student, Russian state Humanitarian University (Moscow, Russia). E-mail: j.pelenitsyna@gmail

* Исследование выполнено в рамках темы НИР «Эволюционный континуум рода Ното». Подтема «Антропология древних и современных популяций» 
части изучаемой территории в краниологическом отношении практически не отличается от капоидов (бушмены и готтентоты) Южной Африки, при этом резко отличается от скотоводческих популяций этой территории.

Ключевые слова: краниология, краниотип, тропиды, пигмеи, транссахарская Африка

\section{Введение}

Настоящая работа является продолжением и развитием темы более ранней нашей статьи «Краниотипы Африканского континента» (Пестряков, Григорьева 2013). Основные выводы этой предшествующей статьи здесь изложены ниже.

1. Наиболее древнее население тропической транссахарской Африки, видимо, было, согласно нашим выводам, представлено двумя основными различными краниотипами.

2. На западе континента в зоне тропических дождевых лесов первичное население сохранилось в виде малочисленных пигмейских популяций, для которых типичны следующие краниологические особенности: малая общая величина черепной коробки (параметр ОРВ), укороченная по величине продольного диаметра, сравнительно с фоном ближайших негрских популяций, по форме средневысокая и среднеширокая. Подобные серии мы назвали пигмеоидами, выделяя их среди краниотипа западных тропидов.

3. На востоке тропической Африки, где доминируют саванны, древним антропологическим субстратом современного населения видимо были капоиды, классическими представителями которых в настоящее время являются бушмены. Для них наиболее характерными краниологическими чертами, кроме относительно малой абсолютной величины черепной коробки (единственно, в чём наблюдается их сходство с пигмеями), является выраженная её удлинённость по форме (параметр УД), и не менее выраженная низкосводность черепа (параметр УГ). Последняя особенность выделяет этот краниотип из всего населения тропиков нашей планеты, для которого обычна как раз высокосводность черепа. Это позволяет выделять подобные серии черепов в специфический локальный краниотип капоидов.

У этого, гипотетически первичного, населения транссахарской Африки абсолютно доминировал присваивающий тип хозяйства, который ныне сохранился лишь в популяциях пигмеев в гумидной зоне тропиков (в Центральной Африке), и в популяциях бушменов в аридной зоне (на нагорьях Восточной и Южной Африки).

Дальнейшая судьба этих древнейших краниологических типов населения транссахарской Африки существенно различается. После возникновения древнейшего ближневосточного очага производящего хозяйства (так называемой неолитической революции) началось распространение земледелия и скотоводства в Африке южнее Сахары.

В гумидных тропиках стало господствовать земледельческое население, этносы которого теснили (и при смешении, видимо, ассимилировали) автохтонные пигмейские популяции, у которых господствовал присваивающий тип хозяйства. Малочисленные племена последних в настоящее время сохранились лишь в виде небольших вкраплений в собственно негрский массив на обширной территории от Камеруна и Габона на западе до Руанды на востоке. 
Настоящая статья может рассматриваться, сравнительно с предыдущей нашей работой по африканской краниологии, и как более расширенная, и как более суженная.

С одной стороны, в этой работе мы привлекаем данные по женским краниосериям изучаемой территории, которые ранее не учитывались. Далее, если в литературе найдены индивидуальные метрические краниологические данные конкретных серий, то мы выделяли их отдельные фракции, отличающиеся друг от друга по типу ростового процесса. Принципы выделения отдельных типов роста черепной коробки мы обосновали и применили в одной из более ранних наших статей (Пестряков, Григорьева 2017).

С другой стороны, здесь мы сузили территориальное пространство изучаемых краниосерий. В Западной части тропической Африки: рассматривались лишь краниосерии территории Габона и бассейна реки Конго. В статье будем называть для краткости эту территорию Центральной Африкой. Полностью исключалось рассмотрение краниосерий территории Верхней Гвинеи (кроме сравниваемой серии из Камеруна), так как в предыдущей статье показано их существенное краниологическое отличие от таковых территорий Нижней Гвинеи и бассейна Конго.

Другое ограничение касалось анализа краниосерий Восточной части транссахарсой Африки. Здесь мы исключили из рассмотрения все кочевые популяции этой территории, так как, согласно выводом нашей предшествующей статьи (Пестряков, Григорьева 2013), они в краниологическом отношении резко отличаются как от земледельцев этой территории, так и от бушменов, охотников и собирателей аридной зоны, сохранившихся в основном в Южной Африке. Это избавляет нас от повторов некоторых выводам, уже изложенных в предыдущей нашей работе по африканской краниологии.

В данной статье наше внимание полностью сосредоточено на краниологических отличиях населения Западной тропической Африки бассейна Конго и прилегающих территорий (Габон), т.е. Центральной Африки, с одной стороны, и нагорий Восточной Африки, с другой стороны.

Физико-географическая граница между этими частями Африки отчётливо выражена. Для смешения населения равнинной и среднегорной территорией Габона и огромной котловиной реки Конго и её притоков нет серьёзных географических, в том числе и климатических препятствий. Это зона господства тропических дождевых лесов. Она отделена от восточноафриканских аридных нагорий серьёзными физико-географическими препятствиями. Восточнее бассейна реки Конго расположены меридионально направленные хребты гор Митумба, высотой от 2500 до 3000 метров от уровня моря. Северным, также меридиональным их продолжением, является высокогорный массив Рувензори, с пиком Маргерита высотой в 5120 м, а также вулканически активная высокогорная система Вирунга. К востоку от этих горных систем находится великая африканская тектоническая рифтовая зона, тянущаяся также в меридианальном направлении, от Эфиопских гор на севере до реки Замбези на юге. В грабенах этой зоны расположены многочисленные глубоководные озёра. Цепочка наиболее крупных из них: озёра Альберта, Эдуарда, Киву, Танганьика, Ньяса. Далее к востоку и югу от этих озёр находится обширное плоскогорье с преобладающими высотами 1500-2500 м, над которым возвышаются самые высокие горы Африки - потухшие вулканы Кения и Килиманджаро. Климат здесь с выраженным засушливым сезоном, вместо дождевых лесов господствуют саванны. Итак, между изучаемыми нами Западной и Восточной 
частями тропической экваториальной Африки находятся серьёзные орографические и климатические географические преграды, серьёзно препятствующие свободным миграционным потокам автохтонного населения.

Следует отметить, что распространение с севера в южном направлении производящего хозяйства на территории Западной и Центральной Африки затруднено. «Нельзя забывать, что на большей части континента экваториальный лес представляет собой барьер для продвижения скота и злаков, служивших главными составляющими производящей экономики к северу от экватора.... Восточный сектор был единственной частью суданской Африки, из которой скот и злаки могли быть легко переданы на юг» (Оливер, Фэган 1986: 85). Поэтому восточнее, в более аридной зоне восточноафриканского плоскогорья, кроме земледельцев сформировалось значительное число кочевых скотоводческих этносов - банту-язычных и нилото-язычных популяций коровопасов.

\section{Материалы и методы}

В настоящей работе использовались данные, взятые из соответствующих литературных источников. Среднегрупповые величины метрических признаков серий территории Габона и Заира (племенная группа тетела в низовьях р. Конго) взяты из статьи Шамла (Chamla 1954) и работы Алексеева (Alexejev 1973). Индивидуальные краниологические данные этих серий взяты из работы Бенингтона и Пирсона (Benington, Pearson 1912). Данные по серии басуку из юго-восточного Заира и одной серии пигмеев представлены в работе Рибота (Ribot 2003). Данные по трём мужским черепам пигмеев даны в сводке Хауэлса (Howells, интернет сайт). С.В. Васильев также предоставил данные измеренных им четырёх мужских черепов пигмеев. К этим группам добавлена одна сборная серия Дронтшилова из Камеруна (Drontschilow $1913)$ - территории лежащей на границе Верхней и Нижней Гвинеи.

Краниосерии Восточной Африки представлены серией тейта из Кении, сборной серией территории Танганьики из статьи Элизабет Китсон (Kitson 1931), сборной серией из Уганды в статье Горни (Gorny 1957) и серией хуту из статьи Рибота (Ribot 2002).

Кроме трёх основных диаметров черепной коробки (признаки №1, №8, №17 по списку Р. Мартина) и их индексов (8:1 и 17:8) здесь, как в других наших краниометрических работах приводятся нестандартные обобщённые параметры. 1) Общая ростовая величина черепной коробки (ОРВ), вычисляемая векторным сложением её трёх взаимноперпендикулярных диаметров. 2) Указатели долихоидности (УД), брахиоидности (УБ) и гипсиоидности (УГ), вычисляемые как средняя геометрическая отношений соответствующего диаметра черепа к двум другим, умноженная на 100. 3) Степень сферичности указывает на близость формы черепной коробки к сфере. Вычисляется по формуле СС = (200 -УД +УБ+УГ)/3.

Кроме среднегрупповых величин метрических признаков изучаемых серий, мы выделили в тех, где даны индивидуальные их величины, отдельные фракции, имеющие различные типы ростовых процессов. Обоснование и сам метод выделения подобных фракций изложены в более ранней нашей работе (Пестряков, Григорьева 2017).

Согласно выводам нашей предшествующей работы по африканской тематике капоиды (бушмены и готтентоты) жители Южной Африки, в краниологическом отношении значительно ближе к земледельцам Восточной Африки, чем к другим 
хозяйственным, территориальным и лингвистическим объединениям населения африканского континента. Поэтому данные по мужским и женским краниосериям капоидов мы также включили в анализ. Из работы Шрубсалла (Shrubsall 1922) взяты данные по сериям прибрежных бушменов, бушменов Капского полуострова, бушменов Калахари. Ещё две серии бушменов взяты из работ Алеша Хрдлички (Hrdlic$k a, 1928)$ и Хауэллса (Howells, Internet-site). Данные по сериям средневековых палеобушменов (Рит-Ривер и Абрахамстаун) взяты из работы Хеннеберга и Стейна (Henneberg, Steyn 1993). Данные по сериям готтентотов взяты из работ Райтмайра (Rightmire 1970) и В.П. Алексеева (Alexeyev 1973).

\section{Обсуждение результатов}

В нижеприведённых таблицах даны среднегрупповые данные краниосерий и их типологически различных ростовых фракций (если таковые выделяются) по 10 признакам: четырём, касающимся абсолютных размеров черепной коробки и шести - её формы.

Ниже дана таблица 1 среднегрупповых значений десяти отобранных нами краниологических параметров в изучаемых краниологических сериях и их отдельных ростовых фракций, выделенных по согласованности изменчивости параметров формы черепной коробки (УД, УБ, УГ).

Таблица 1

\section{Среднегрупповые величины параметров изученных серий и их ростовых фракций (мужчины).}

\begin{tabular}{|c|c|c|c|c|c|c|c|c|c|c|c|}
\hline & $\mathrm{N}$ & 1 & 8 & 17 & OPB & $8: 1$ & $17: 8$ & уд & УБ & УГ & $\mathrm{CC}$ \\
\hline $\begin{array}{l}\text { Кения, серия } \\
\text { тейта }\end{array}$ & 33 & 184,0 & 129,8 & 129,1 & 259,6 & 70,6 & 99,5 & 142,2 & 84,3 & 83,6 & 75,2 \\
\hline $\begin{array}{l}\text { Тейта, } \\
1 \text { фракция }\end{array}$ & 9 & 185,1 & 133,6 & 124,7 & 260,1 & 72,2 & 93,3 & 143,5 & 88,0 & 79,3 & 74,6 \\
\hline $\begin{array}{l}\text { Тейта, } \\
2 \text { фракция }\end{array}$ & 8 & 183,3 & 125,9 & 132,9 & 259,0 & 68,7 & 105,6 & 141,7 & 80,7 & 87,5 & 75,5 \\
\hline $\begin{array}{l}\text { Тейта, } \\
3 \text { фракция }\end{array}$ & 15 & 184,5 & 129,7 & 129,7 & 260,2 & 70,3 & 100,0 & 142,2 & 83,9 & 83,8 & 75,2 \\
\hline $\begin{array}{l}\text { Уганда, } \\
\text { сборная серия }\end{array}$ & 82 & 183,5 & 133,4 & 127,7 & 260,3 & 72,7 & 95,9 & 140,6 & 87,2 & 81,7 & 76,1 \\
\hline $\begin{array}{l}\text { Уганда, } \\
1 \text { фракция }\end{array}$ & 25 & 183,5 & 131,2 & 131,6 & 261,1 & 71,5 & 100,4 & 139,6 & 84,4 & 84,9 & 76,6 \\
\hline $\begin{array}{l}\text { Уганда, } \\
2 \text { фоакция }\end{array}$ & 27 & 179,7 & 134,7 & 128,1 & 258,6 & 75,0 & 95,2 & 136,8 & 88,8 & 82,4 & 78,1 \\
\hline $\begin{array}{l}\text { Уганда, } \\
3 \text { фракция }\end{array}$ & 30 & 186,9 & 134,0 & 124,1 & 261,3 & 71,7 & 92,7 & 144,8 & 88,1 & 78,6 & 74,0 \\
\hline $\begin{array}{l}\text { Танганьика, } \\
\text { сборная серия }\end{array}$ & 37 & 180,8 & 130,4 & 129,4 & 257,8 & 72,1 & 99,2 & 139,2 & 85,3 & 84,3 & 76,8 \\
\hline
\end{tabular}


Таблица 1 (продолжение)

\begin{tabular}{|c|c|c|c|c|c|c|c|c|c|c|c|}
\hline & $\mathrm{N}$ & 1 & 8 & 17 & OPB & $8: 1$ & $17: 8$ & Уд & уБ & УГ & $\mathrm{CC}$ \\
\hline Хуту & 41 & 184,7 & 134,8 & 126,4 & 261,3 & 73,0 & 93,7 & 141,5 & 88,3 & 80,1 & 75,6 \\
\hline $\begin{array}{l}\text { Бушмены, } \\
\text { Рит Ривер }\end{array}$ & 27 & 182,0 & 135,0 & 128,0 & 260,3 & 74,2 & 94,8 & 138,5 & 88,4 & 81,7 & 77,2 \\
\hline $\begin{array}{l}\text { Бушмены, } \\
\text { Абрахамстаун }\end{array}$ & 8 & 185,0 & 136,0 & 127,0 & 262,4 & 73,5 & 93,4 & 140,8 & 88,7 & 80,1 & 76,0 \\
\hline $\begin{array}{l}\text { Бушмены } \\
\text { Howells }\end{array}$ & 41 & 178,4 & 133,6 & 122,5 & 254,4 & 75,0 & 91,8 & 139,6 & 90,5 & 79,4 & 76,8 \\
\hline $\begin{array}{l}\text { Бушмены } \\
\text { Hrdlicka }\end{array}$ & 15 & 182,6 & 135,7 & 127,5 & 260,8 & 74,3 & 94,1 & 138,9 & 88,9 & 81,0 & 77,0 \\
\hline $\begin{array}{l}\text { Бушмены } \\
\text { береговые }\end{array}$ & 45 & 180,9 & 138,0 & 123,6 & 258,9 & 76,3 & 89,6 & 138,5 & 92,2 & 78,2 & 77,3 \\
\hline $\begin{array}{l}\text { Бушмены } \\
\text { Капские }\end{array}$ & 62 & 179,4 & 134,4 & 124,9 & 256,6 & 74,9 & 92,9 & 138,5 & 89,8 & 80,4 & 77,2 \\
\hline $\begin{array}{l}\text { Бушмены } \\
\text { Калахари }\end{array}$ & 19 & 180,7 & 134,1 & 126,0 & 257,9 & 74,2 & 94,0 & 139,0 & 88,9 & 80,9 & 80,3 \\
\hline $\begin{array}{l}\text { Готтентоты, } \\
\text { Rightmire }\end{array}$ & 16 & 182,9 & 135,8 & 129,3 & 261,9 & 74,3 & 95,2 & 138,0 & 88,3 & 82,0 & 77,4 \\
\hline $\begin{array}{l}\text { Готтентоты, } \\
\text { Алексеев }\end{array}$ & 34 & 185,3 & 133,4 & 130,4 & 262,9 & 72,0 & 97,8 & 140,5 & 85,8 & 82,9 & 76,1 \\
\hline $\begin{array}{l}\text { Габон, } \\
\text { сборная серия }\end{array}$ & 66 & 180,1 & 136,5 & 135,5 & 263,5 & 75,8 & 99,3 & 132,5 & 87,4 & 86,4 & 80,5 \\
\hline $\begin{array}{l}\text { Габон, } \\
1 \text { фракция }\end{array}$ & 24 & 178,0 & 137,8 & 132,8 & 261,4 & 77,4 & 96,5 & 131,7 & 89,7 & 84,8 & 81,0 \\
\hline $\begin{array}{l}\text { Габон, } \\
2 \text { фракция }\end{array}$ & 29 & 182,6 & 135,5 & 135,6 & 264,8 & 74,2 & 100,1 & 134,8 & 86,2 & 86,2 & 79,2 \\
\hline $\begin{array}{l}\text { Габон, } \\
3 \text { фракция }\end{array}$ & 13 & 177,8 & 134,6 & 139,4 & 263,1 & 75,7 & 103,6 & 129,9 & 85,5 & 90,1 & 81,9 \\
\hline $\begin{array}{l}\text { Камерун, } \\
\text { сборная }\end{array}$ & 84 & 180,1 & 138,8 & 135,0 & 264,4 & 77,1 & 97,3 & 131,6 & 89,0 & 85,4 & 80,9 \\
\hline $\begin{array}{l}\text { Конго, батете- } \\
\text { ла, сборная }\end{array}$ & 48 & 178,0 & 138,6 & 134,0 & 262,5 & 77,9 & 96,8 & 130,7 & 89,8 & 85,4 & 81,5 \\
\hline $\begin{array}{l}\text { Конго, } \\
1 \text { фракция }\end{array}$ & 28 & 182,6 & 140,8 & 135,4 & 267,5 & 77,1 & 96,3 & 132,3 & 89,6 & 84,5 & 80,6 \\
\hline $\begin{array}{l}\text { Конго, } \\
2 \text { фракция }\end{array}$ & 18 & 170,9 & 135,2 & 131,8 & 254,7 & 79,1 & 97,6 & 128,1 & 90,1 & 86,7 & 82,9 \\
\hline Басуку & 53 & 178,2 & 128,7 & 130,9 & 255,8 & 72,2 & 101,7 & 137,3 & 84,3 & 86,4 & 77,8 \\
\hline $\begin{array}{l}\text { Пигмеи, } \\
\text { Васильев }\end{array}$ & 4 & 175,5 & 129,5 & 131,0 & 254,4 & 78,3 & 101,2 & 134,7 & 85,4 & 86,9 & 79,2 \\
\hline Пигмеи, Ribot & 9 & 175,4 & 134,8 & 130,0 & 256,6 & 76,9 & 96,4 & 132,5 & 89,3 & 84,5 & 80,5 \\
\hline $\begin{array}{l}\text { Пигмеи, } \\
\text { Howells }\end{array}$ & 3 & 177,0 & 130,3 & 135,7 & 258,3 & 73,6 & 104,1 & 133,1 & 84,1 & 89,3 & 80,1 \\
\hline
\end{tabular}


По данным этой таблицы, включая серии, из которых не выделены ростовые фракции, и ростовые фракции разделённых серий, но исключая сами эти серии, построена дендрограмма, учитывающая межгрупповую изменчивость параметров размера и формы черепной коробки (рис.1).

Согласно этой дендрограмме все серии и фракции серий чётко, как по заказу, разделились на два кластера: в одном из них все краниосерии, взятые в Восточной (восточноафриканские земледельцы) и Южной (бушмены и готтентоты) Африки, в другом оказались все серии и фракции серий Камеруна, Габона и Конго вместе с пигмеями (Центральная Африка). При этом краниосерии и их фракции земледельцев и западной (Центральная Африка) и восточной частей изучаемой территории на дендрограмме расположены вперемешку с группами охотников и собирателей (c бушменами на востоке, с пигмеями на западе). Это свидетельствует или о значительной метисации между группами земледельцев с соседними группами охотников и собирателей, и о том, что земледельческие этносы формировались на соответствующем этно-антропологическом субстрате охотников и собирателей.

Чем же отличаются краниологические характеристики

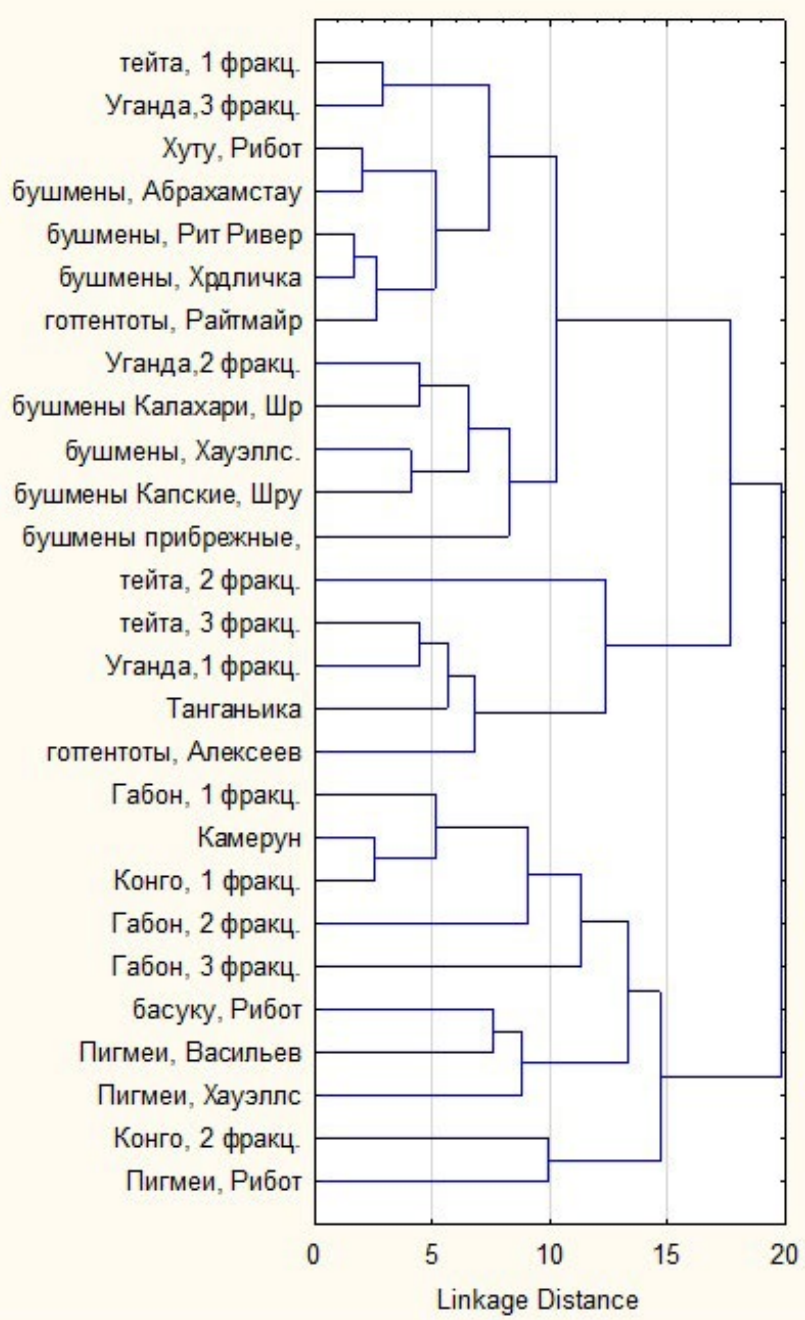

Рис.1. Дендрограмма взаиморасположения изученных краниосерий, а также ростовых фракций, выделенных по согласованности изменчивости параметров формы черепа - УД, УБ, УГ (мужчины). популяций этих двух территорий Африканского континента?

Рассмотрим краниологические характеристики серий и фракций серий Восточной и Южной Африки, и отдельно от них, серии и фракции серий Центральной Африки: таблицы 2 и 3, соответственно. Число нераздельных серий и фракций этих двух территориальных подразделений у нас оказалось неодинаково: в восточной части -18 , а в западной (центральноафриканской - 10). 


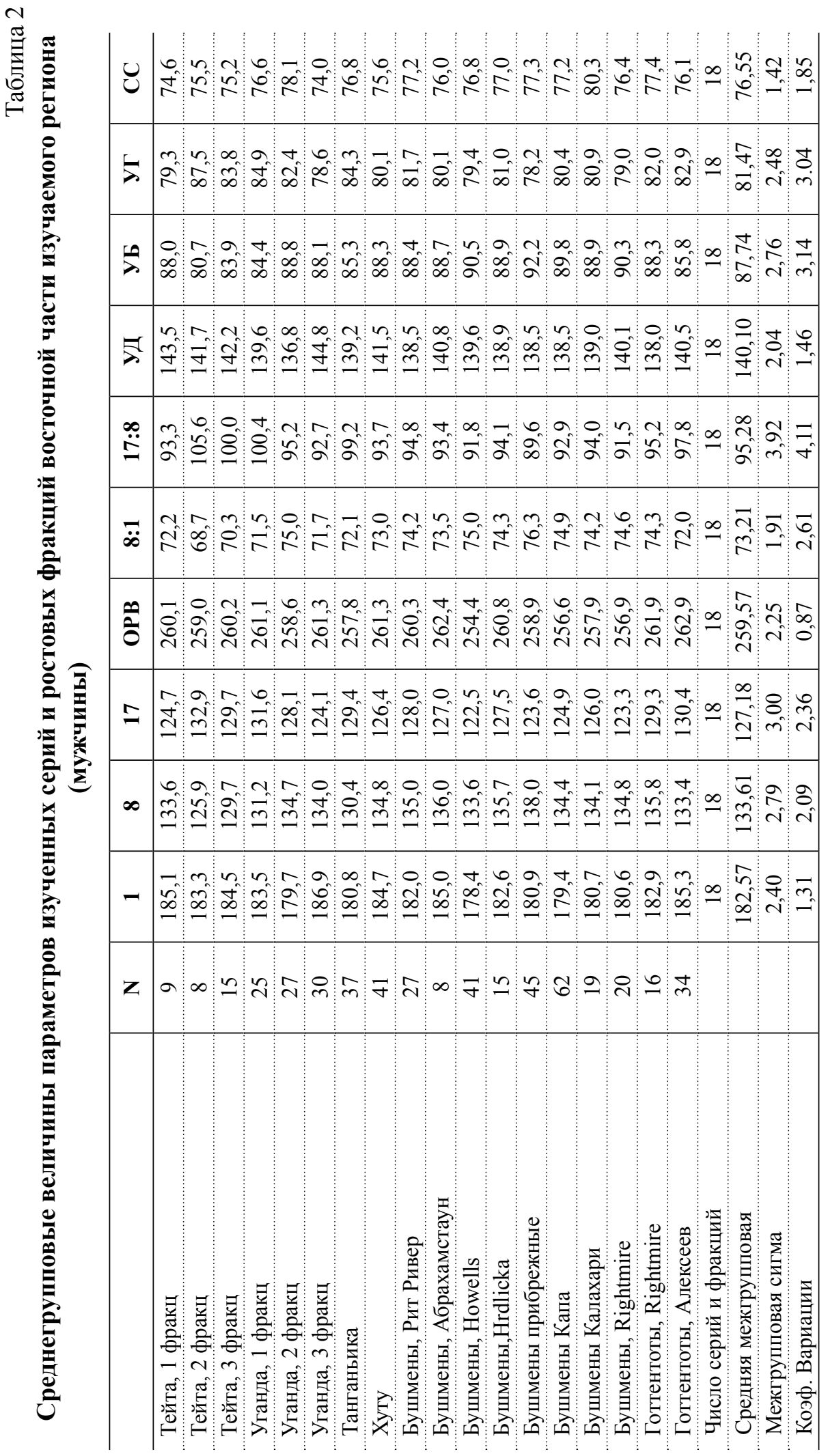




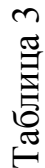

U

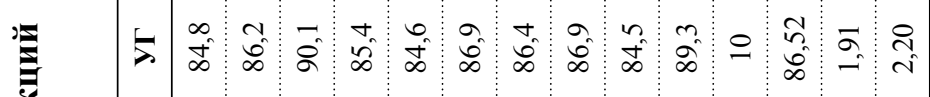

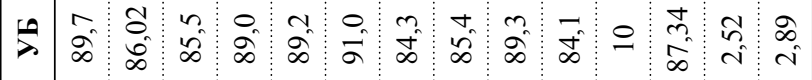

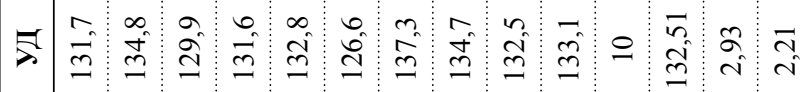

产

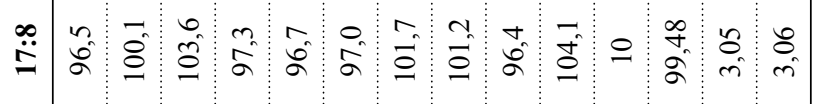

产 至

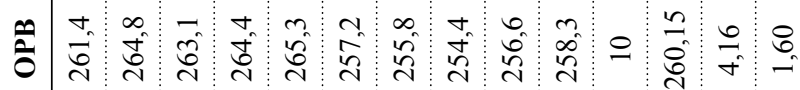

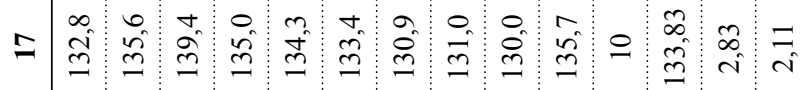

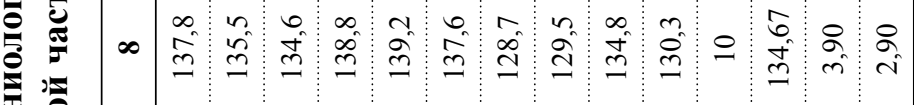

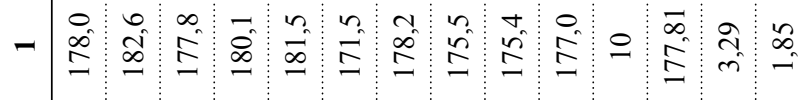

z

อ.

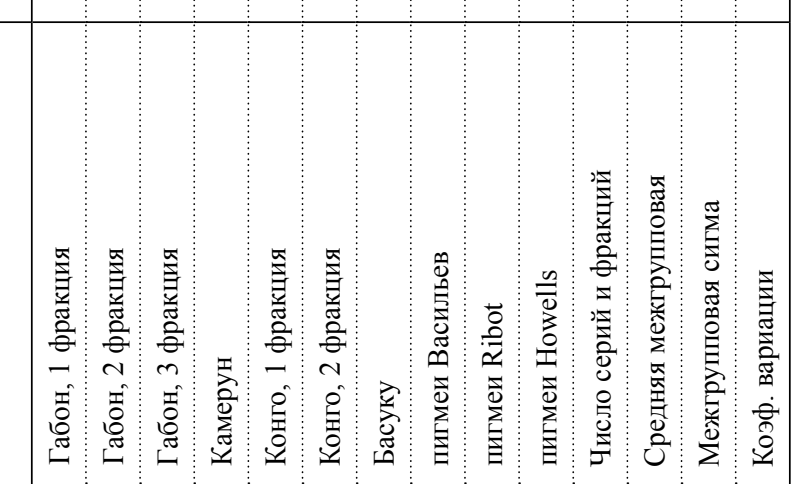




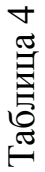

u

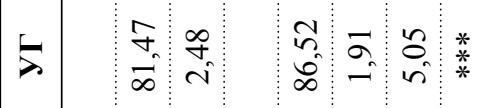

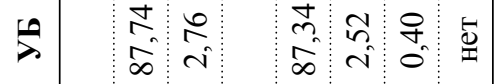

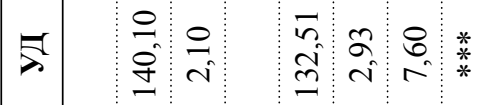



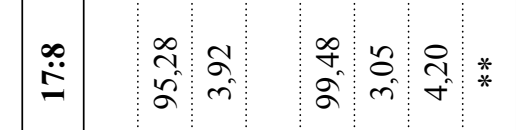

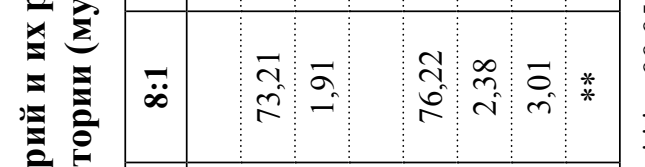

经

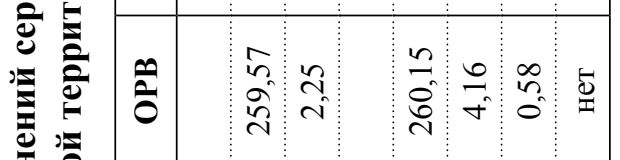



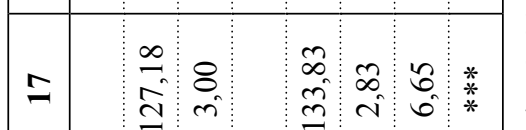

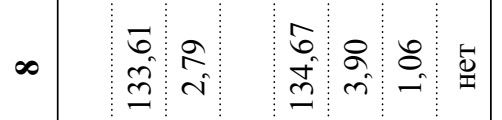

in 0 क

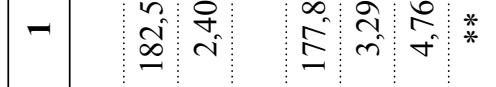

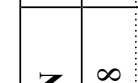

$\infty \quad 0$

1

$+\quad: \quad: \quad$

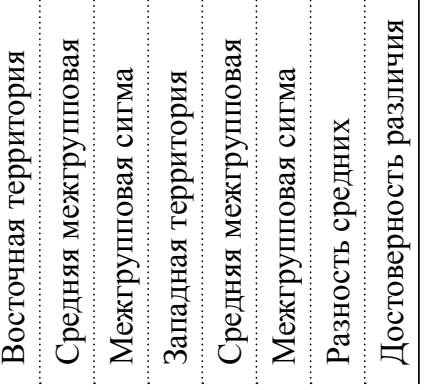

要

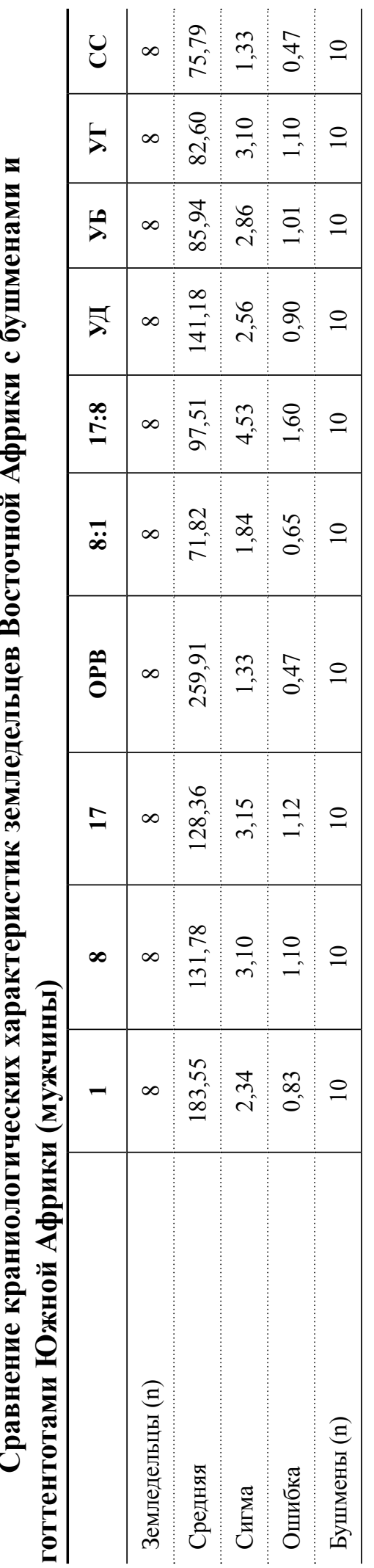




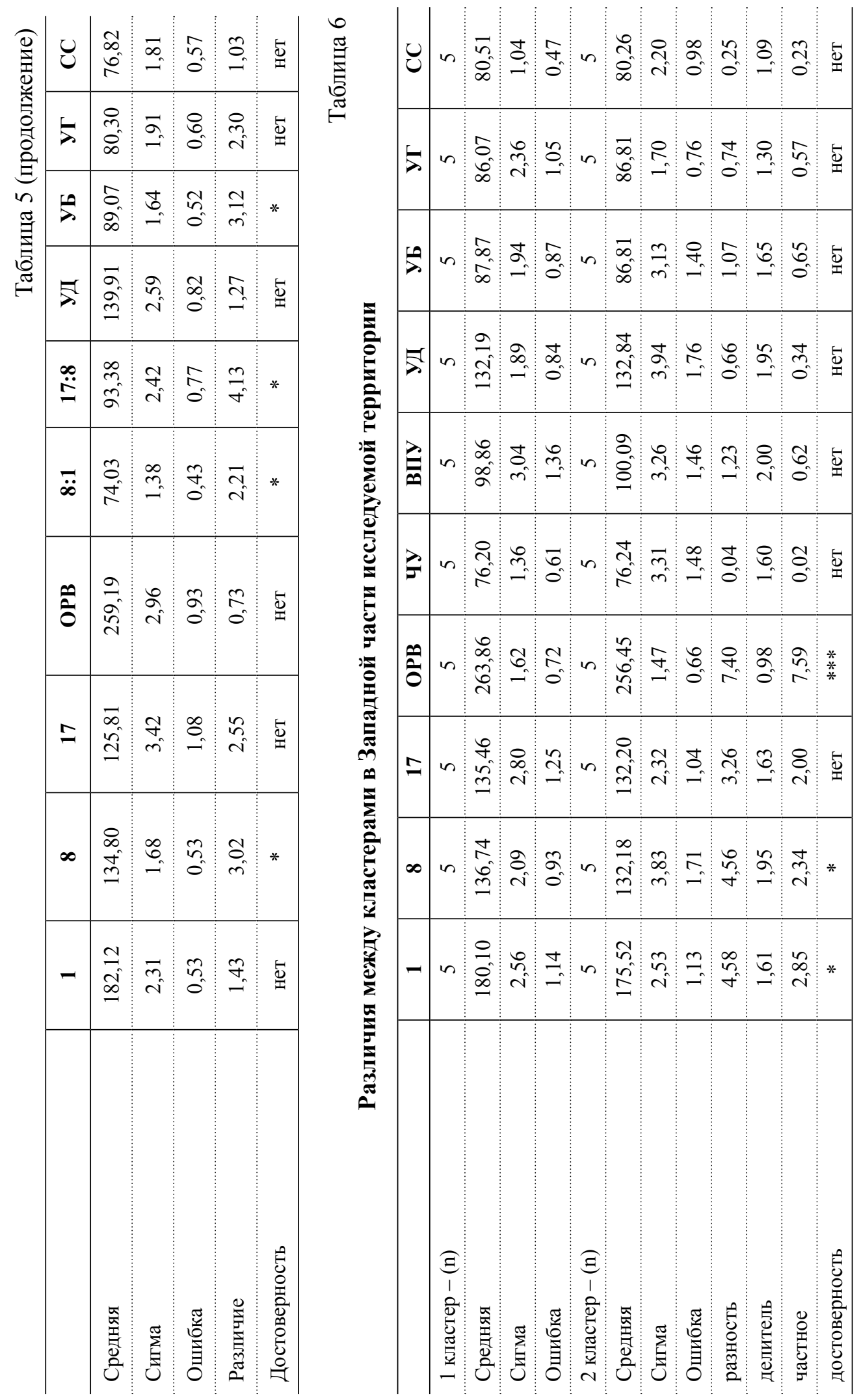




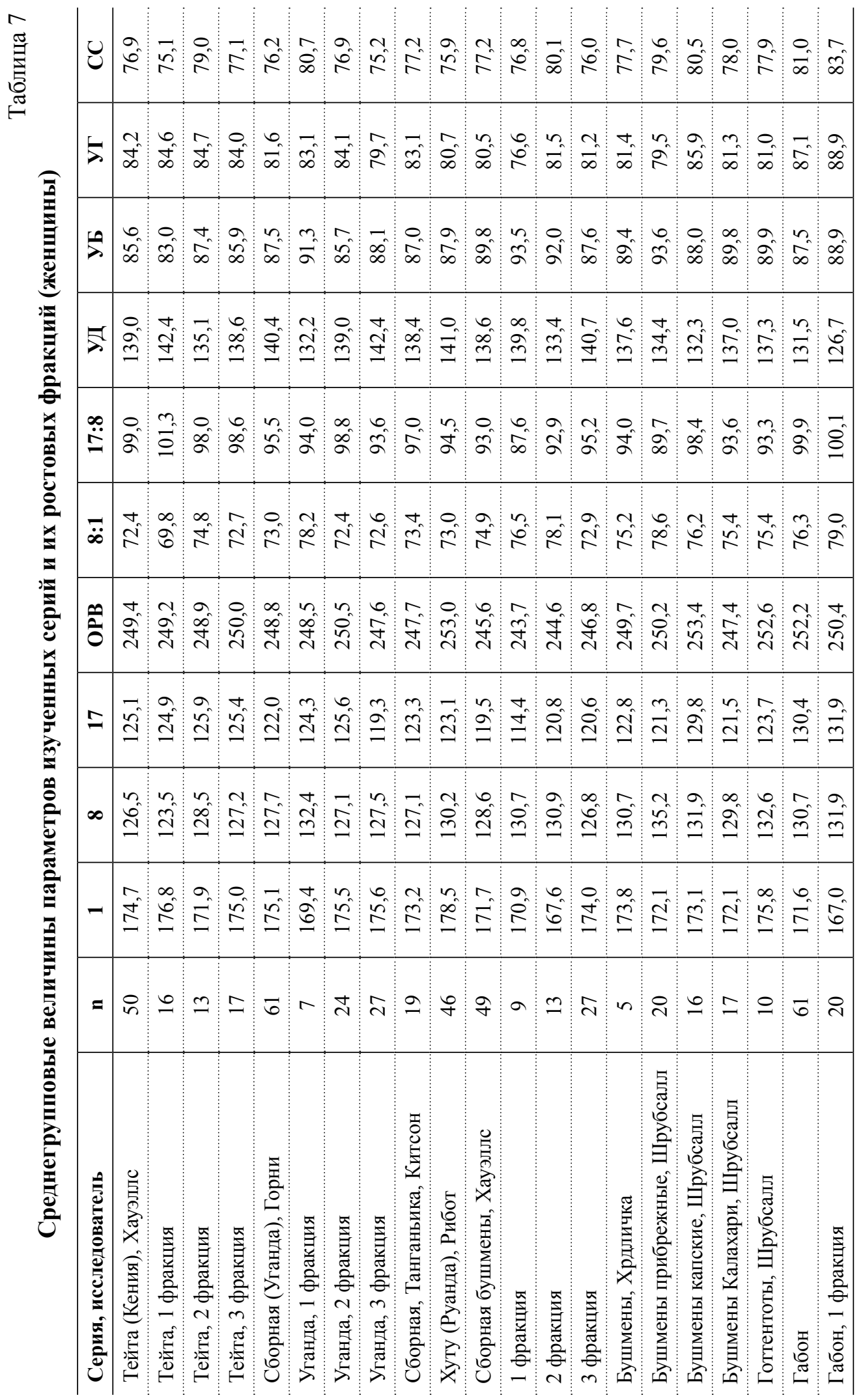




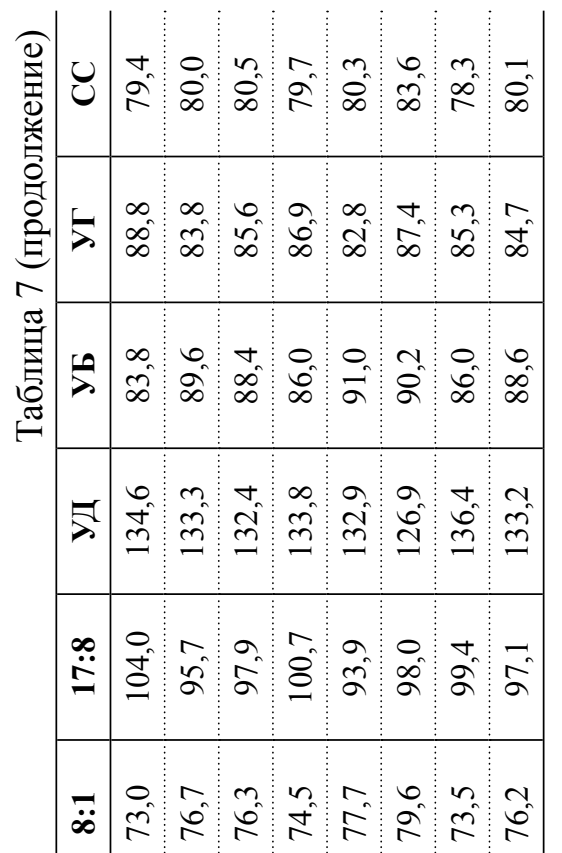

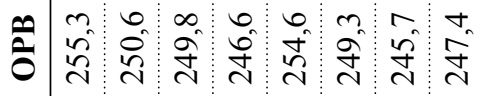

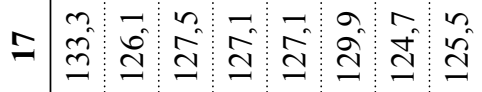

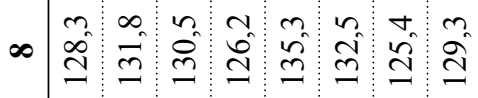

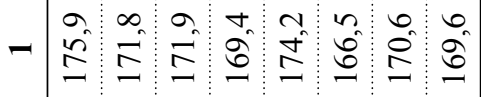

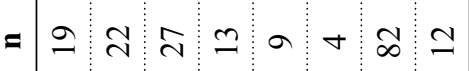

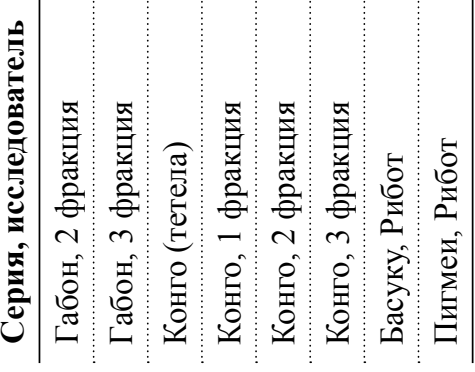

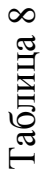

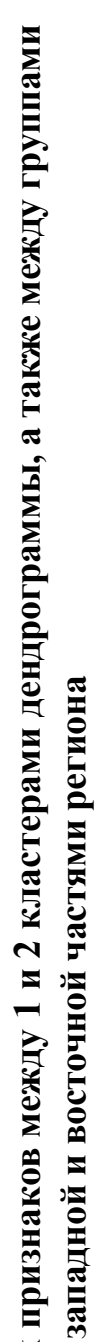

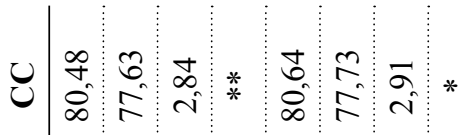

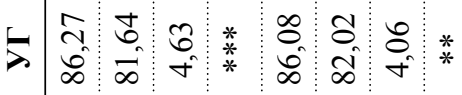

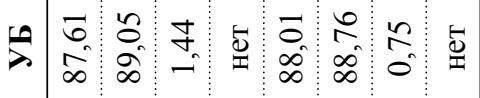

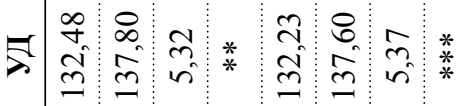

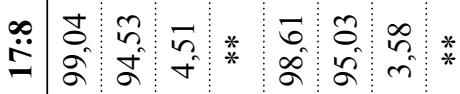

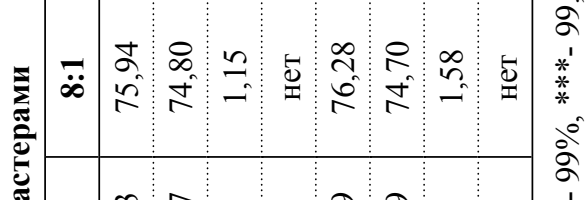

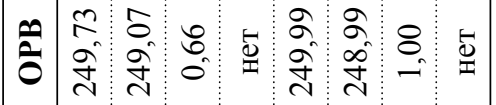

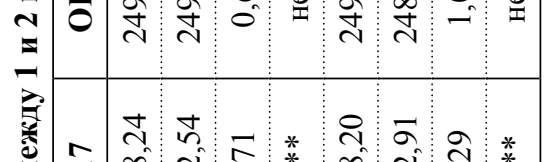

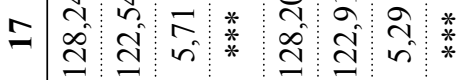

葛

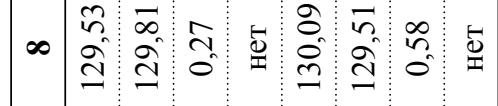

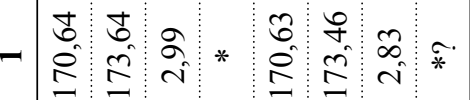

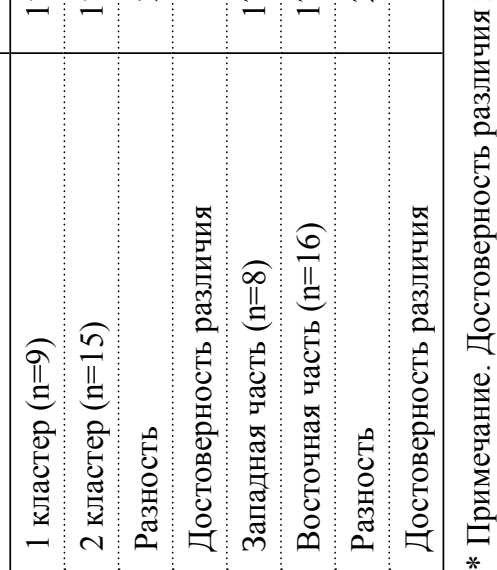


По абсолютному размеру черепной коробки, по абсолютной величине её поперечного диаметра и по параметру УБ (показывающему эту величину, относительно к величинам двух других основных диаметров черепа) достоверного различия между сравниваемыми территориями Африки нами не обнаружено. Зато абсолютные величины продольного и высотного диаметров черепа, а также индексы, связанные с этими величинами, показывают резкое различие краниологических выборок этих двух территорий: на втором и даже на третьем уровне достоверности, принятых в антропометрической практике. В целом, на западе изучаемой территории (Центральная Африка) черепная коробка относительно и абсолютно короче и выше. Здесь доминирует мезокрания, на востоке - долихокрания. Степень сферичности черепной коробки (эволюционно прогрессивный признак) в западной части более выражена.

Используя данные таблицы 2, разделим наши восточноафриканские краниологические группировки на две части: земледельцы Восточной Африки и бушмены и готтентоты. А затем, сравним эти группировки между собой (таблица 5).

Бросается в глаза, что абсолютная величина черепной коробки (параметр ОРВ) в западной части исследуемой территории варьирует значительно больше, чем в восточной части - коэффициент межгрупповой вариации этого признака здесь равен 4,16 против 2,25 . Точно так же величины других анализируемым признаков (за исключением высотного диаметра черепа) в западной части территории варьируют больше (иногда значительно больше), чем в восточной. Причина, видимо в том, что черепа пигмейских краниосерий более существенно отличаются от соседних негрских, даже тех, в которых явно прослеживается их примесь. На территории же восточноафриканского плоскогорья земледельческие популяции меньше отличаются от собственно капоидов (бушменов). Последние (бушмены) видимо являются антропологическим субстратом первых.

В таблице 4 представлены сравнения по t-критерию Стъюдента различиий изучаемых признаков между нашими основными территориальными объединениями (восточным и западным).

Среди диаметров черепной коробки в межгрупповом отношении здесь более всего варьирует высота (признак 17), менее всего продольный диаметр (признак 1). Черепной указатель в среднем долихокранный $(73,21)$, варьирует от ультрадолихокрании $(68,7)$ до мезокрании $(76,3)$. Высотно-поперечный указатель в среднем равен 95,28 (поперечный диаметр обычно превосходит по величине высотный). Но в двух фракциях серии тейта (Кения) и одной фракции серии Уганды средняя величина высотного диаметра превышает таковую поперечного.

В таблице 3 приведены аналогичные данные по западной части изучаемой территории.

Сравнение краниосерий (и их фракций) земледельцев Восточной Африки и бушменов, как целого, показало, что краниологически они мало различаются друг от друга. Именно, у бушменов черепа более широкие и более низкие по абсолютным размерам и по указателям. Общая величина черепной коробки (признак ОРВ) у этих двух объединений практически одинакова, хотя межгрупповая дисперсия этого признака у земледельцев в два раза меньше $(\sigma=1,33$ против $\sigma=2,96)$.

Рассмотрим краниологическую изменчивость западной части изучаемого региона (территория Габона и Конго) - данные таблицы 3. Согласно дендрограмме (рис.1) краниосерии и выделенные фракции краниосерий западной части изучаемого региона 
(Центральная Африка) в числе 10 разделяются поровну на два субкластера. В один из них вошла сборная серия Камеруна, все три фракции Габона и одна фракция территории Конго. Во второй субкластер - вторая фракция Конго, серия басуку и все три серии пигмеев. Используя данные таблицы 3 рассмотрим различия между этими субкластерами.

Согласно таблице, достоверные различия между кластерами наблюдаются по длине и ширине черепной коробки (на первом уровне достоверности) и ее общей величине (на третьем уровне достоверности). Из этого следует, что в центральном районе тропической Африки (котловина бассейна р. Конго) негрские племена имеют значительную примесь пигмеев, которые, как известно, отличаются малой величиной не только длины тела, но и черепной коробки. По форме черепной коробки между этими кластерами различия недостоверны. Представляет значительный интерес процесс формирования пигмеоидной краниологической формы в населении Центральной Африки.

Наша конголезская серия тетела территориально близка к низовьям Конго. То есть тому месту, где в средние века сформировалось государство Конго, которое тесно связано с этногенезом и расселением бантуязычных народов экваториальной Африки. Выходцы из Катанги расселялись по саванне к западу, следуя по многочисленным притокам р. Конго. В XVI веке это государство пережило серьезную катастрофу, связанную с нашествием народа яга. «Придя с глубин Экваториальной Африки, этот народ жил в постоянном движении.... Сложен был и его этнический состав. Женщины, подобно мужчинам, участвовали в сражениях, им запрещалось иметь детей: каждого новорожденного убивали. Чтобы восполнить неизбежный урон, яга охотно включали в свой состав мальчиков и девочек- подростков тех племён и народов, на территории которых они вторгались и чьё взрослое население истребляли в подавляющей массе или поголовно» (Орлова, Львова 1978: 70). В этногенезе басуку, видимо, серьезную роль сыграло движение яга. К сожалению, у нас нет краниологических данных по составу яга, но очень вероятно, что значительную их часть составляли пигмеи.

Аналогично с вышеописанным анализом по мужским сериям, проводилось рассмотрение женских краниосерий и выделяемых из них ростовых фракций. В нижеследующей таблице 7 даны соответствующие величины изучаемых краниологических признаков у женщин этой территории.

По данным этой таблицы построена дендрограмма расстояний между изучаемыми краниологическими группами (рис.2). Как и в случае мужских краниосерий здесь мы исключаем те сборные серии, по которым выделены фракции с различным типом ростовых процессов. Оставшийся материал собран в 24 группы - 15 фракций и 9 серий нерасчленённых на ростовые фракции.

В отличие от аналогичной дендрограммы, построенной по мужским краниологическим материалам, здесь не получилось чёткой разбивки на восточную и западную части изучаемой территории. В верхнем кластере из девяти групп две этнически близки восточноафриканским популяциям: капские бушмены крайнего юга африканского континента и одна фракция тейта (Кения), т.е. с наиболее северной части изучаемого нами региона. Остальные семь групп из Габона и Конго. Второй (нижний) кластер объединяет все 14 остальных краниологических групп восточной части изучаемого региона и только одну (вторую фракцию тетела) из Центральной Африки.

В следующей таблице 8 мы представляем средние межгрупповые величины наших краниологических параметров в женских группах этих двух кластеров дендрограммы (рис.2) и достоверность этих различий. Но также, чтобы не множить число 
таблиц в нашей статье, рассчитаем различие между группами западного региона и восточного региона исследуемой территории.

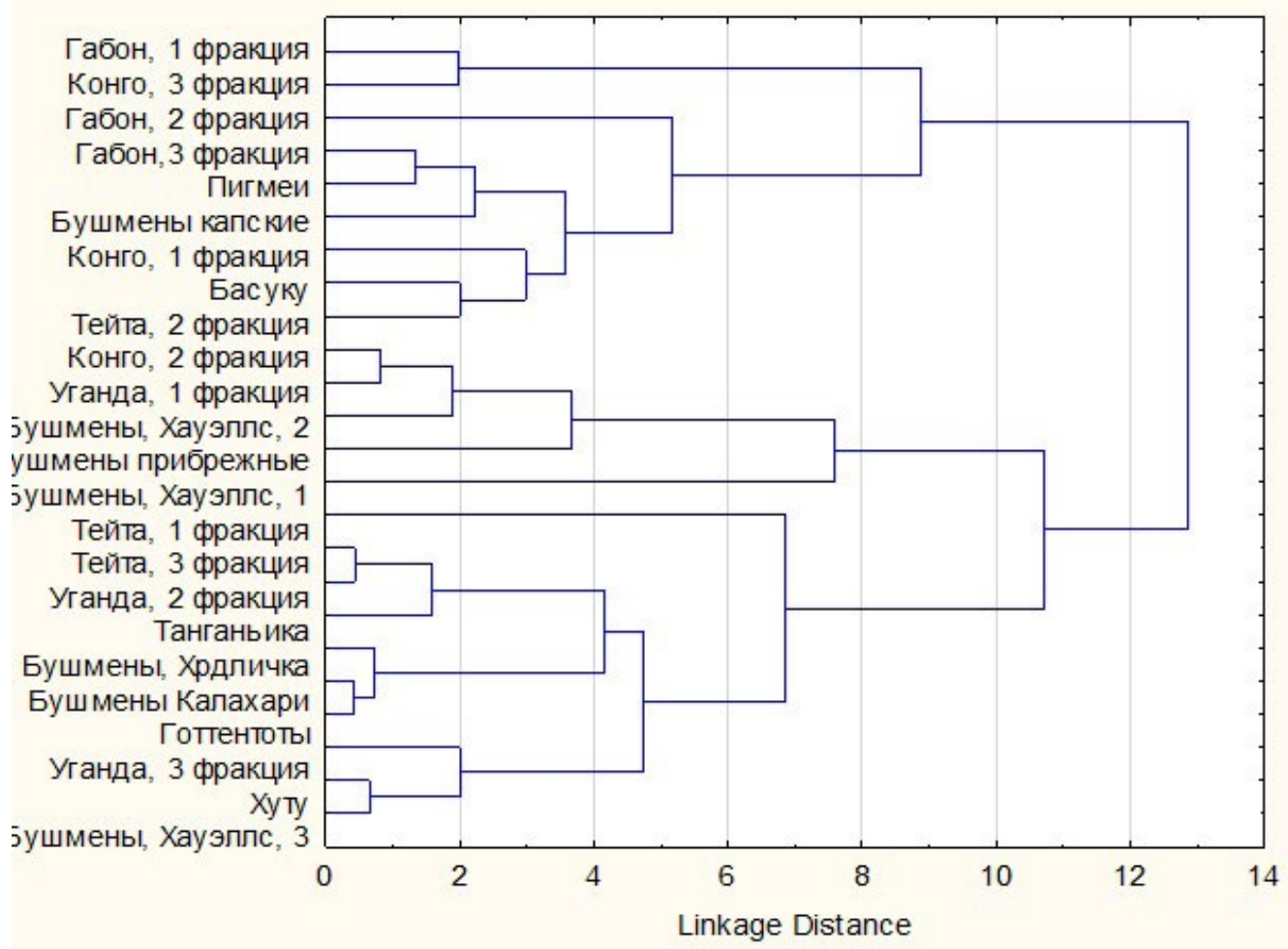

Рис.2. Дендрограмма взаимных расстояний между сериями и выделенными фракциями женщин изучаемой территории Африки.

Из этой таблицы ясно, что различия между кластерами дендрограммы расстояний среди женских групп (краниосерий и фракций краниосерий) показывают практически ту же картину, что и при разделении их на западный и восточный части исследуемого региона.

Ниже представлены основные выводы настоящего исследования.

\section{Основные выводы}

1. Исследование как мужских, так и женских краниологических серий, и их фракций, различающихся по типу ростовых процессов, указывает на существенное краниологическое отличие автохтонного населения гумидной западной зоны тропической Африки (Камерун, Габон, Конго) от такового более аридной восточной зоны Африки (восточноафриканские земледельцы и капоиды-бушмены). В первом случае исходным этно-антропологическим субстратом более позднего негрского земледельческого населения были пигмейские популяции (охотники и собиратели тропических дождевых лесов). Во втором случае таковым субстратом для восточноафриканских земледельцев были бушменские популяции. 
2. По абсолютной величине черепной коробки между средними межгрупповыми величинами западной и восточной частями изучаемого региона достоверного различия нет, как у мужчин, так и у женщин.

3. Однако по форме черепной коробки отличия очевидны. Для всех западных краниосерий и ростовых фракций этих серий характерна относительно и абсолютно более короткая и более высокая форма черепа в сравнении с черепами восточной части изучаемого региона. Это также справедливо как для мужчин, так и для женщин. Степень сферичности черепной коробки в западных краниосериях достоверно выше, чем в восточных.

4. При сравнении серий восточноафриканских земледельцев с сериями их вероятного субстрата - с бушменами, наблюдается относительно небольшое отличие: черепа бушменов лишь слегка более низкие и широкие при такой же абсолютной величине.

В западной части изучаемой нами территории наблюдается существенно иная картина.

Здесь, как сказано выше, этно-антропологическим субстратом для земледельцев гумидной зоны были пигмейские популяции (охотники и собиратели). Но пигмеи, войдя в состав негрских земледельцев этого региона, выявляются в их краниосериях малой абсолютной величиной черепной коробки. Такая малая величина черепной коробки фиксируется не только в собственно пигмейских сериях, но также в краниосерии басуку. Дисперсия этого признака среди мужских групп на западе изучаемой территории больше, чем на востоке у мужчин почти в два раза, у женщин также намного больше.

Опираясь на эти факты, на уровне гипотезы можно предположить, что переход к земледелию, сопровождавшийся постепенной ассимиляцией протобушменских популяций в Восточной Африке начался намного раньше, чем в западной части изучаемой нами территории. В сложении современного негрского населения бассейна р. Конго значительную роль сыграло движение варварских орд яго, которые инкорпорировали в свои популяции антропологический субстрат современных им пигмеев. Из этого следует, что сложение земледельческих этносов территории бассейна Конго произошло сравнительно недавно и не смогло гомогенизировать это население в краниологическом отношении.

\section{Научная литература}

Алексеев В.П., Дебеи Г.Ф. Краниометрия. Методика антропологических исследований. М.: Наука, 1964.

Бунак B.B. Основные морфологические черты черепа человека и их эволюция // Рус. антропол. журн., 1922. Т. 12. Кн. 1/1. С. 4-54.

Оливер Р., Фэган Б. Рождение бантуязычной Африки // Из истории африканского средневековья. Статьи британских учёных. М.:Наука, Главная редакция восточной литературы, 1986. C. $77-147$.

Орлова А.С., Львова Э.С. Страницы истории великой саванны. М.:Наука, Главная редакция восточной литературы, 1978.

Пестряков А.П. Расы человека в краниологической классификации населения тропического пояса // Современная антропология и генетика и проблема рас у человека / Ред. И.М. Золотарева. М.: ИЭА РАН, 1995. С.43-90.

Пестряков А.П., Григорьева О.М. Краниологическая дифференциация современного населения // Расы и народы. Ежегодник. № 30. М.: Наука, 2004. С. 86-131. 
Пестряков А.П., Григорьева О.М. Краниотипы африканского континента // Вестник антропологии. 2013. № 3 (25). С. 22-36.

Пестряков А.П., Григорьева О.М. К типологии ростовых процессов черепной коробки человека // Вестник Московского университета. Серия XXIII. Антропология. 2017. № 1. C. 89-102.

Рогинский Я.Я., Левин М.Г. Антропология. М., «Высшая школа», 1978.

Alexejev V.P. Craniological material from new Guinea, Indonesia and the Malayan peninsula // Anthropologie. 1973. No. XI/3. Brno. P. 201-248.

Benington R.C., Pearson K. A study of the Negro Skulls with special reference to the Congo and Gaboon Crania // Biometrica. Jan. 1912. Vol. 8, no. 3/4. P. 292-339.

Drontschilow K. "Metrische Studien an 93 Schadeln aus Kameru // A.f.A. .1913. Bd. XL. P. 161-183.

Gorny S. Crania Africana. Uganda. Wroclaw, 1957.

Henneberg M. and Steyn M. Depart. of human Biology, University of the Witwatersrand, Parktown 2193, and depfrt. of Anatomy, University Trends in Cranial Capacity and Cranial Index in Subsaharan Africa during the Holocene American Journal of Human Biology. 1993. Vol. 5. P. 473-479.

Howells W.W. Craniometric data set. URL: http://web.utk.edu/ auerbach/HOWL.htm (Дата обращения 15.01.2020).

Hrdlicka A.: Catalogue of human crania in the United States national museum collectilns. Procceedings of the of the United States national museum. Vol. 71. Washington, 1928.

Kitson Elisabeth. A Study of the Negro Skull with Special Reference to the Crania from Kenya Colony // Biometrika. Dec. 1931. Vol. 23, no. 3/4. P. 271-314.

Ribot I. Craniometrical analysis of Central and East Africansin relation to history. A case study based on unique collectionsof known ethnic affiliatio // Anthropologica et Preahistorica. 2003. Vol. 114. P. 25-50.

Righmire G.P. Bushman, Hottentot and South African Negro crania studied by distance and discrimination// American Journal of Physical Anthropology. 1970b. Vol. 33. P. 169-196.

Shrubsall F. C. A Note on Bushman Craniology // Man. Dec. 1922. Vol. 22. P. 185-187.

\section{References}

Alekseev, V.P., and G.F. Debets. 1964. Kraniometriia. Metodika antropologicheskikh issledovanii. [Craniometry. Methods of anthropological research]. Moscow: Nauka.

Alexejev, V.P. 1973. Craniological material from new Guinea, Indonesia and the Malayan peninsula. Anthropologie XI/3: 201-248.

Benington, R.C., Pearson K. 1912. A study of the Negro Skulls with special reference to the Congo and Gaboon. Crania. Biometrica 8 (3/4): 292-339.

Bunak, V.V. 1922. Osnovnye morfologicheskie cherty cherepa cheloveka i ikh evoliutsiia [Basic morphological features of the human skull and their evolution]. Russkii antropologicheskii zhurnal 12 (1-2): 24-52.

Drontschilow, K. 1913. Metrische Studien an 93 Schadeln aus Kameru. A.f.A. XL: 161-183.

Gorny, S. 1957. Crania Africana. Uganda. Wroclaw.

Henneberg, M. and M. Steyn. 1993. Depart. of human Biology, University of the Witwatersrand, Parktown 2193, and depfrt. of Anatomy, University Trends in Cranial Capacity and Cranial Index in Subsaharan Africa during the Holocene. American Journal of Human Biology 5: 473-479.

Howells W.W. Craniometric data set. URL: http://web.utk.edu/ auerbach/HOWL.htm (Дата обращения 15.01.2020).

Hrdlicka, 1928. A. Catalogue of human crania in the United States national museum collectilns. Procceedings of the of the United States national museum, Vol. 71. Washington.

Kitson Elisabeth. 1931. A Study of the Negro Skull with Special Reference to the Crania from Kenya Colony. Biometrika 23 (3/4): 271-314.

Oliver, R., Fegan B. 1986. Rozhdeniye bantuyazychnoy Afriki [The birth of Bantu-speaking Africa]. Iz istorii afrikanskogo srednevekovia. Stati britanskikh uchenykh, 77-147. Moscow: Nauka. 
Orlova, A.S., and E.S. Lvova. 1978. Stranitsy istorii velikoy savanny [Pages of the history of the great Savanna]. Moscow: Nauka. Glavnaya redaktsiya vostochnoy literatury.

Pestriakov, A.P. 1995. Rasy cheloveka v kraniologicheskoi klassifikatsii naseleniia tropicheskogo poiasa [Human races in the craniological classification of the tropical population]. In: Sovremennaia antropologiia i genetika i problema ras u cheloveka [Current anthropology and genetics and the issue of races and man], edited by I.M. 3olotareva, 43-90. Moscow: IEA RAN.

Pestriakov, A.P., Grigor'eva O.M. 2004. Kraniologicheskaia differentsiatsiia sovremennogo naseleniia [The craniological differentiation of the contemporary population]. In: Rasy i narody. Ezhegodnik № 30 [Races and peoples: an annual edition no. 30], 86-131. Moscow: Nauka.

Pestryakov, A.P., Grigoryeva O.M. 2013. Kraniotipy afrikanskogo kontinenta [Craniotypes of the African continent]. Vestnik antropologii 3 (25): 22-36.

Pestryakov, A.P., Grigoryeva O.M. 2017. K tipologii rostovykh protsessov cherepnoy korobki cheloveka [On the typology of growth processes in the human cranium]. Vestnik Moskovskogo universiteta XXIII. Antropologiya 1: 89-102.

Ribot, I. 2003. Craniometrical analysis of Central and East Africansin relation to history. A case study based on unique collectionsof known ethnic affiliatio. Anthropologica et Preahistorica 114: 25-50.

Righmire, G.P. 1970b. Bushman, Hottentot and South African Negro crania studied by distance and discrimination. American Journal of Physical Anthropology 33: 169-196.

Roginskii, Ia.Ia., Levin M.G. 1973. Antropologiia [Anthropology]. Moscow: MGU.

Shrubsall, F. C. 1922. A Note on Bushman Craniology. Man 22: 185-187.

Pestriyakov, Aleksandr P., Grigorieva, Olga M., Pelenitsina, Yulia V.

\section{Tropical Trans-Saharan African Population Genesis: Craniological Aspect}

This article continues a study of cranial growth on the example of the population of tropical Trans-Saharan Africa. The cranial samples of Gabon, basin of the Congo River (the Western part), and East African farmers and Capoids - Bushmen and Hottentots (the Eastern part) were analyzed. Male and female cranial samples were studied separately. Crania of some samples clustered according to the type of growth processes in the crania. Comparative analysis showed that the cranial samples (and clusters inside them) from the West of the studied region, as a whole, differ significantly from those from the East in the shape of the skull. This is clearly seen in the male sample, but less obvious in the female one. The overall size of the cranium in the West is significantly more variable than in the East. This is because of a Pygmy admixture in the population of equatorial rainforest, which are associated with a small size of the cranium. There is no such difference between East African farmers and the craniologically similar Capoids (Bushmen and Hottentots). This leads to two main conclusions. First, the population of the Western (humid) part of Equatorial Africa formed as a mixture of larger-headed agricultural groups with Pygmies, who had smaller crania. Second, the agricultural population of the Eastern (more arid) part of the studied territory is almost identical in craniological terms to the Capoids (Bushmen and Hottentots) of South Africa, while differs significantly from the pastoralist population of this territory.

Keywords: craniology, craniotype, tropids, pygmies, trans-Saharan Africa 